\title{
YA1.- U.MUERSITY
}

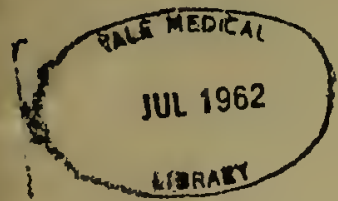

\section{A.RR 211911}

\section{TUBERCULOSIS AND VINEGAR.}

Presented to the Section on Physiology and Dietetics at the Forty-eighth

Annual Meeting of the American Medical Association, held at

Philadelphia, $\mathrm{Pa}$., June Ist to $4^{\mathrm{th}}, 1897$.

BY JOHN ASHBURTON CUTTER,

M.D. ALEATY MEDICAL COLLEGE, MEDICAL DFPARTMENT OF UNION UNIV., 1886;

B. SC., MASSACHUSETTS AGRICULTURAL COLLEGE AND BOSTON UNIVERSITY, I882;

CORRESFONDING MIMBER BOSTCN GYNECOLOGICAL SOCIETY;

MEMBER MEDICAL SOCIETY, BOROUGH OF THE BRONX, NEW YORK CITY.

\section{INTRODUCTORY.}

The enormous amount of work done in bacteriologic lines as to tuberculin has been of such little avail as to treatment and prevention, that $I$ have no hesitation in bringing before the Section, in a few words, a record of work that has been done on other lines and to the glory of medicine, in that this work has cured the desperately sick and prevented the pre-tubercular becoming tubercular.

Note, April 15, 1898.-This article was published in The Journal of the American Medical Association, February 5 , I 898, in full except references to Victor Hugo and Chas. Reade, here found on pages 2 and 3 ; and also published in Scientific American Supplement, April 9, 1898 , commencing at heading BIOLOGICAL.

This reprint contains the original matter as laid before the Section. Space forbids greater amplification. A future effort will be made to demonstrate, and easily, why all hogs do not die of hog cholera and all men of tuberculosis when fed on sour foods. This is legitimate work for the physician, because his labors are constantly to throw the balance between life and death on the right side, and such labor demonstrates to him the wonderful vis mediatrix nature (mediating force of nature), which of ten conquers under adverse circumstances.

As it is, thousands die of tuberculosis who would live if rightly fed, and millions of dollars are lost by hog cholero. and cattle tuberculosis because, again, wrong feeding. Verbum sap. 


\section{IISTORICAL.}

Dr. John Christian read a Latin inaugural thesis at Jena, October, 1729 , in which reference is made to the coagulation of living blood by vinegar, which he says dissolves silica and poisons like viper's venom. He laid down the law, "Causa coagulationis sanguinis est acidum."

Victor Hugo, in "Les Miserables," in "Fantine," Book III., Chapter VII., "The IVisdom of Tholomyes," puts into the mouth of said Tholomyes: "Well, be it so; but, "beauties, remember this: you eat too much sugar. "You have but one fault, oh women! It is that of nib"bling sugar. Ah, consuming sex, the pretty, little white "teeth adore sugar. Now listen attentively! Sugar is a "salt. Every salt is desiccating. Sugar is the most "desiccating of all salts. It sucks up the liquids from the "blood through the veins; thence comes the coagulation, "then the solidification of the blood; thence tubercles in "the lungs; thence death. And this is why diabetes "borders on consumption."

In Charles Reade's novel, "Foul Play," the heroine is sick. Her father, General Rolleston, bluntly asks Dr. Valentine what is the matter with his daughter. "Disease of the lungs," said the doctor simply. When on a voyage from Sydney to England, the story reads, "She was not sea-sick, but thoroughly out of sorts, and in one week became perceptibly paler and thinner than when she started." She said to a clergyman on board: "I have fits of coughing, not frequently but violent, and the blood often comes fiom my lungs. That is a bad sign, you know. I have been so for months. Now I am a good deal wasted." When her confidant asked to be her physician, she said: "I have my own physician." The reply was: "No donbt; but he shows me his incapacity by allowing you to live on pastry and sweets-things that are utter poison to you. Disease of the lungs is curable, but not by drugs and unwholesome food." (Italics mine.) The ship was scuttled. The heroine found safety on an island, and had to live mainly on turtle meat. 
I find in the text: "For some time Helen had been advancing in health and strength. But when the rains declined considerably and she was all day in the air, she got the full benefit of the wonderful climate, and her health, appetite, and muscular vigor became truly astonishing, especially under what Hazel called the turtle cure, though indeed she was cured before. She ate three good meals a day, and needed them, for she was up with the sun and her hands and feet never idle till he set. Four months on the island had done this." Describing the scene of the father finding the shipwrecked daughter, the text says: "Ere he could take a step there came flying to him, with little screams and inarticulate cries, no living skeleton, nor consumptive young lady, but a grand creature, tanned here and there, rosy as the morn and full of lusty vigor."

Charles Reade, in another part of this novel, puts into the mouth of the clergyman the statement that he has medical authorities as to the relations of sweets and pastries to consumption. I have had a scholar at work in the British Museum trying to run down this line of medical history, but have not received returns. "Foul Play" was written somewhere in the fifties.

Victor Hugo must have had his attention called to the souring properties of sugars on the blood. These are matters for further study.

In "The Relation of Alimentation and Disease," Dr. James H. Salisbury recounts his investigations made on $\mathrm{I}, 028$ hogs fed with sour foods in 1858 . Salisbury in the preface, page iii, says: "I had been a graduate of Albany Medical College, and in 1850 entered upon the practice of medicine. I was immediately and forcibly struck by the almost entire want of medical knowledge in regard to the true causes of disease, and by the consequent uncertainty that must and did exist as to the means of combating and curing pathologic states." Salisbury's first publication relating to foods that ferment into alcohol and vinegar and are thereby causative of consumption of the bowels and lungs was made in 1864 in the Surgeon-General's 
report of Ohio. This paper and the matter found in "The Relation of Alimentation and Disease" (published 1888) contain enough to show this investigator's work as to the relations of vinegar and tuberculosis; yet I believe that medicine was not wholly the chaos he considered it when he started to practise in 1850 . Honor to whom honor is due ; honor to Salisbury for his colossal experiments in feeding hogs to death with sour foods! (I would that some of the quidnuncs in bacteriology would enlarge their ken and get away from the bacteria and study yeasts, alcoholic and vinegar.) Honor to the Europeans who recognized the souring properties of certain foods before the time of Salisbury's publications!

In the bibliography appended, much of which is from the publications of this Association, I show what has been done by an American writer, Dr. Ephraim Cutter. The numbers noted in text refer to said bibliography.

\section{BIOLOGICAL.}

“ThE MORPHOLOGY OF THE BLOOD IN HEALTH IS AS FOLLOWS: ${ }^{38}$ "Color.-Bright, fresh, clear, ruddy, strong. Clottings, rapid and firm.

"Red corpuscles.-Arrange themselves in nummulations, or are scattered evenly over the field; normal in size; nonadhesive; central depression well marked on both sides; periphery well rounded, clean-cut. Hold coloring matter firmly. Pass readily to and fro through the fibrin filaments. Appear fresh and fair.

"White corpuscles.-Normal in size, not enlarged by inter. nal collections of foreign bodies. Amoboid movements strong or not. Proportion, I to 300 of red corpuscles. Consistence good, not sticky. Color a clean white. Freely moving at will.

"Serum.-Clear and free at first sight from any form. After fifteen minutes most delicate semi-transparent fibrin filaments appear, forming a very light network in the field, which offers no obstacle to the passage of the corpuscles." 
THE MORPHOLOGY OF THE BLOOD IN TUBERCULOSIS IS AS FOLLows:

"First or incubative stage. - Red blood corpuscles are less in number, ropy and sticky more or less, but not much changed otherwise.

"Second stage of transmission.-I. Red corpuscles: Color pale, non-lustrous; not clear-cut, not ruddy. Consistence, sticky and adhesive. Coating of neurin removed. Not so $\mathrm{n}$ umerous as in normal blood. Owing to the increased size and strength of the fibrin and the stickiness, they form in ridges, rows, but not so marked as in rheumatic blood. They accumulate in aggregations of confused masses, like droves of frightened sheep. They adhere to each other, and are rotten, as it were, in texture. 2. White corpuscles: Enlarged and distended by the mycoderma aceti, or spores of vinegar yeast, that are transmitted into the blood stream from the intestines. 3. Serum more or less filled with the spores of mycoderma aceti, or vinegar yeast. These occur either singly or in masses of spores, which is the common form in which they are found wherever vinegar is produced. The fibrin filaments are larger, stronger, more massive than in health, and form under the microscope a thick network which is larger, stronger, and more marked in direct proportion to the severity of the disease or the amount of accumulation. Besides, the serum is apt to be of a dirty ash color. The sticky white corpuscles, the massive fibrin filaments in skeins, and the yeast spores alone or combined, form aggregations, masses, collects, thrombi and emboli which block up the blood vessels of the lungs soonest, because exposed to cold air the most of any viscus. The blood vessels contract, and thus arrest the thrombi and form a heterologous deposit, which is called tubercle.

"The third stage of tubercular deposit. - These deposits increase so long as vitality subsists in the tubercle and surroundings. When vitality ceases the tubercle softens or breaks down. Sometimes, if the process is very slow and life slightly inheres in it, the proximate tissue undergoes fatty infiltration which preserves it from readily breaking 
down. The morphology of the blood is the same for the second and third stages of consumption.

"Fourth stage, interstitial death. - The red corpuscles are thinner, paler, much lessened in number, increased in ad. hesiveness, stickiness, and poverty; devoid more or less of neurin. The white corpuscles are fewer in number, more enlarged, often ragged and rough; distended with spores of mycoderma aceti; more adhesive, and sticky. The scrum. -Fibrin filaments are thickened, stronger, more massive, and more skeins of them present. The collects of mycoderma aceti are very much larger and more numerous; in moribund cases I have seen them so large as almost to fill the field of the microscope."

\section{PRE-TUBERCULOSIS. ${ }^{10}$}

"The idea that diseases have periods of incubation preceding their full development accords with other facts in animal and plant biology. It is to be expected that tuberculosis of the lungs, for example, has a pre-stage. In fact, pre-tuberculosis exists, and clinically means that the morphology of consumptive blond is present to a lesser extent than in tuberculosis; that the essence of pre-tuberculosis is in these vegetations in the blood, which, coming from the fermentations in the alimentary canal, pass the barriers of the intestinal epithelia and float about in the blood stream of consumption any time during one year before the necrosis or sphacelation or breaking down of the lungs, sufficient to be detected by the usual signs furnished by auscultation and percussion. It is evident that in such spongy bodies as the lungs small deposits may escape physical macroscopic exploration. But the microscope will detect this stage."

VINEGAR AND HOG CHOLERA. ${ }^{1013}$

"Seven years ago my son and I independently studied hog cholera on a large stock farm in Western Massachusetts, autopsying animals immediately after death (1) by the disease, and ( 2 ) by slaughter in early and late stages of complaint, the proprietor giving us every opportunity of macroscopic and microscopic examinations of blood and tissues 
of his animals, as he considered his herd doomed. We found, independently: I. The blood morphology of tubercle and embolism. 2. Tuberculosis of lungs, bowels, skin. 3. Recent fibrin clots in heart. 4. Partial paralysis of hind extremities. 5. Paralysis of nerve centres.

"Causation of this epidemic.- $x$. Steady feeding of ensilage which is loaded with vinegar and vinegar yeast. 2. Swill food brought from outside. 3. Cold weather. One and two, predisposing causes; three, exciting cause."

The hog physically is much like man; man is very much of a hog as to eating food that makes swill, and hence suffers much from tubercle.

\section{WORLD-WIDE RELATIONS.}

The Esquimau does not die of tuberculosis. He lives on animal food, yet for months of each year he breathes a vitiated atmosphere.

Tuberculosis ravages in the South, where little good beef is eaten and instead very much of vegetable food. Some filteen years ago a resident of Savannah, Ga., came under treatment in New York. He changed his mode of living and became a beef-eater. Since that time all of his family have died of tuberculosis; he lives because of his beel-eating habits. The negro dies of tuberculosis. Causes: poor food, the mental strain of trying to reach the white man's level, and syphilis with its grandchild scrolula.

Tuberculosis has ravaged in New England, especially the rural portion, with its diet of pie three times a day, and baked beans, which latter chemically are splendid food for cattle, but for man not fit, unless cooked for many hours. Tuberculosis is now diminishing in New England, because they are eating more beef and drinking more milk, although there has been very much of foolish opposition to the use of milk.

Cattle are dying in New England and other places of tuberculosis, and so long as the silo, with its alcoholic and 
vinegary products, is used, so long will farmers lose their cattle. A man imported a splendid herd from the Island of Jersey some fourteen years ago. He had a silo. $\mathrm{He}$ was expostulated with as to the dangers of feeding sour foods to his cattle. He persisted, and all died of either tuberculosis or heart disease. ${ }^{30}$

The easiest way to externinate the Indian is to give him plenty of white flour and rum. Tuberculosis always follows.

There is no "royal road" to the cure of tuberculosis or its prevention. The various tuberculin treatments are based on the principle of injecting an attenuated dose of poison into the human system, and this poison, like strychnia and many other drugs, stimulates nature, and in some lines by inflammation, to cure the diseased lungs and joints. One that has been afflicted with cough, weakness, emaciation, pain, and dread of impending death, would only too eagerly accept such a treatment. Yet in its very best it only eflects results, it does not touch causes; and when one sees men like Robert Koch wrestling on this line, while lives go out because they will persist in ignoring the causative relations of vinegar and vinegar yeast to tuberculosis, it makes one wonder at this neglect of general principles. So long as the cause is being put in the system, so long will tuberculosis continue; and it is strange that these followers of Koch also ignore the positive relations of syphilis and scrofula to consumption. As far as I can learn, the majority of medical men are using, as a basis of their treatment, animal food; but why should they gravitate to the other side and give the causes of the disease, to wit, fermented milk foods such as kumyss, etc., pastry, starches, sugars, vegetable foods of many kinds that cannot digest because of the weakness of the bowels, salads that soon make swill, and jellies and colloids, to name no more? These same men also neglect the value of the study of the mor- 
phologies of the blood, sputum, fæces, and urine according to the rules laid down by American observers.

At whose door shall be laid the blame of the ignoring of the incalculable value of the diagnosis of the pre-tubercular state, which diagnosis can be made before the lungs are affected, and before there is any sputum to find bacilli in or diseased spots in the lungs for tuberculin to react on? This knowledge of the pre-tubercular state is of the greatest value to humanity of anything in the practice of medicine.

The Dr. Cyrus Edson treatment was based on so-called logical grounds as to certain relations of carbolic acid to the human body in tuberculosis; yet he adds pilocarpine to his remedy to stimulate white blood corpuscle activity. He therefore indirectly recognizes the presence of vinegar yeast in the blood, and that anything which helps the action of white blood corpuscles will help the patient for a time. Why not put the axe to the root of the tree and stop the formation of this vinegar yeast in the blood?

Some Europeans are now using raw beef. Why they do not give their patients broiled beef I cannot understand. Raw beef is unpalatable; it promotes tapeworm. The use of beef is the bottom principle in the treatment of tuberculosis, but it should be employed in the form of steaks or roasts, or the first-class top of the round freed from connective tissues by machine or knife and chopping bowl, as the connective tissues are of a colloid nature, and ferment and tend to the production of vinegar yeast. The lean muscle pulp is then moulded into a cake an inch and a half deep, several inches wide, not too tightly pressed together (and in all of its preparation care should be taken to touch as little as possible the meat direct by the hands, as the human animal heat will change the character of the muscle pulp); broil this over a bed of good live coals, a gas stove, or even kerosene flame, turning often, and the resultant should be of a dark-brown color 
on the outside and of a reddish but not raw appearance inside. It is best served on a hot-water plate, and if a little underdone it will cook on the plate when the meat cake is opened. If a hot-water plate cannot be obtained, one can be extemporized by the use of a soup plate filled with hot water, on which is placed another plate with the meat. There cannot be too much care used in the buying of the beef or its preparation, and, if proper caution is taken, the patient will generally eat it with a relish. It should be seasoned with pepper, salt, butter, Worcester. shire sauce, horse-radish, lemon juice, as the patient de. sires.

Lamb, mutton, the dark meat of fowl and game, broiled codfish can be used as changes; the whites of eggs dropped in boiling water and slightly cooked may be taken freely, if the patient is not eating enough of solid food. Some patients will take the whites of from one dozen to two dozen eggs in a day when weak and not able to take other food. Don't do as one woman did; she gave her husband the cooked whites of eggs with plenty of vinegar. The masses of vinegar yeast in the blood were so large and frequent under the microscope that amazement was expressed. The woman protested that she was doing everything absolutely according to order for her husband. As all of his symptoms were worse, and because of this blood morphology of the masses of vinegar yeast, it was insisted that some error was being made, and thus ascertained what she had done.

Vegetable food may be added as follows; Some patients can bear one of the following foods at a meal: cracked wheat, rice, hominy, toasted entire wheat-flour bread, baked potato. It is a hardship at the best to confine patients to close diet, and physicians should give them as much variety as possible; but there is more danger of error on the side of too broad a diet than on that of too narrow a one.

The use of distilled water, or some good spring water 
that has not more than five to ten grains of salts to the gallon, should be persisted in, drank (after boiling) at a temperature of from $100^{\circ}$ to $120^{\circ} \mathrm{F}$. one hour before each meal and on going to bed.

Medicines should be employed in the treatment of tu. berculosis on principles, and the main one is, give no medicine which can ferment into alcohol and vinegar in the alimentary tract. This principle forbids the prescribing of cough syrups and other preparations now largely used.

The skin in tuberculosis is more or less loaded with the vegetations of vinegar yeast. There should be employed daily sponge baths, the water to be hot or cold according to the patient's desires. Ammonia and water in the proportion of two teaspoonfuls to a pint, or the aromatic sulphuric acid, one teaspoonful to a pint, or even the nitro-muriatic acid, one-half teaspoonful to a pint, can be used with great advantage. Rubbing with a saturated solution of spirits and salicin is a good means of toning up the skin and the whole body.

Bacteria or bacilli are babies of vegetations which have become animalized by contact with the human body and human secretions. Robert Koch denonstrated their presence in the sputum of tubercular cases, for which he should receive due credit; but the work which precedes his in time and importance, as showing the real cause of tuberculosis, must not be ignored. The vinegar yeast found in the blood is the second stage of the bacteria, and is found there in the spore form, and sometimes in tubercular cavities we get the third stage of development in the aerial filaments of the vinegar yeast.

Physicians could learn much as to relation of sour foods to tuberculosis in a few months time by experimenting on hogs (not guinea-pigs or rabbits), by feeding a certain number with sour and a certain number with sweet foods, having all in the same building so that they breathe the same air. The beauty of this kind of work is that 
one can kill the animals any time one pleases and know just what is going on.

The Agricultural Experiment Stations of the different States are fully equipped to.make these investigations on hogs. It is necessary, however, that the microscopist who follows the experiments should have a fair working knowledge of the methods of the American observers who have been studying this subject for over thirty years on their patients and with animals. If it is right to rush abroad to Berlin to study cured cases of tuberculosis, some of whom die the day after they are pronounced cured, there can be no harm in studying in America all the work which made cured cases thirty years ago, for such cases are living now.

\section{PROGNOSIS.}

Granted a recognition of the relation of vinegar to tuberculosis, the prognosis can be more definitely made out, for if one is stopping a cause then one has some hope to base his belief of cure on. If one is simply treating results according to tuberculin method, and is still putting in the food which will undergo vinegary fermentation, the prognosis must necessarily be doubtful.

What is the experience of those who recognize the relation of vinegar and tuberculosis? Temperament here comes in. Some of the most appalling cases with many hemorrhages, with the evidence of cavities in both lungs unquestioned, as determined by physical examination of the chest and by the detection of the elastic and inelastic lung fibres in the sputum, have progressed most favorably under proper treatment. Others, who apparently had little disease, went down to death. The rule has had to be laid down that all cases except the moribund should have a chance for treatment. It is a most wonderful thing how Nature endows these cases with hope. Some patients fight indomitably, and, contrary to expectations, they get well. It is not pleasant to look back and con- 
sider the amount of opposition which was placed in the path of those who thirty years ago were endeavoring to help these distressed patients.

But what will you do with cavities? The postmortem evidences of many morgues and dissecting rooms show unquestionably that cavities do heal over and patients live to die of another complaint. An autopsy (1896) showed three small cavities healed in the top of the left lung and two in the right. There was some fatty and calcareous degeneration going on in the base of the left lung; liver somewhat enlarged but normal in structure; no tuberculosis of stomach or bowels; heart normal in size and as to structure; principal symptoms for three years had been of heart exhaustion, needing the greatest of care and attention. Seven years belore her death an eminent medical man stated that she had but three months to live; if her appetite for beef foods, and in fact for piactically all other foods, had not failed three years before her death, she would probably have lived to old age. Of great courage, good judgment, she in her weakness for many months travelled close to the verge of the grave. Of strong affections, her love for her dear ones kept her alive a long time; yet something in her nervous system broke down as to appetite, and death eventually came.

It is cruel to take away, from the very sick, hope. There are many doctors of eminence and influence who literally are executioners because of their brutally taking away all hope. The passionate, anxious, eager holding on to life of the very sick is a matter of divine origin, and I do not propose to stand in the way of that divine gift of the desire for life.

Some patients die from money troubles. Others die from the long-continued opposition of their friends, relatives, and medical men to systemic treatment. It can be thanklully said that this opposition is dying out. Others die because they are associated in herds at the various resorts in the mountains of the South and West and in 
sanatoria, seeing and hearing the consumptives all about them. Such suffer for the privileges of home. They have many comforts taken from them, and are liable, in going South, of getting into a blizzard and have to live in a shelter which is improperly made.

I wish to emphasize that the treatment of tuberculosis must depend upon the family physician. It should com. mence in infancy; the children should be properly fed and taught to avoid sweets and the vegetable foods which do not agree with them, and those who are so unfortunate as to break down with the disease must still be kept at home, or such change of air and climate made as can do good and no harm. There is no question that good air is a wonderful thing, yet we can buy oxygen and force the air alimentation, if necessary, in our cities.

PARTIAL BIBLIOGRAPHY OF EPHRAIM CUTTER, M.D., LL.D.

I. Treatment consumption by animal food. Boston Journal Chemistry, Jan., 1876. 2. November, 1879. 3. Michigan Med. News, Detroit, November, 1879. 4. Ditto, April Io, I880.

5. Transactions American Medical Association, I880; contributed histories of seventy cases, in one-third of whom disease apparently permanently ameliorated.

6. Tubercle parasite. Am. Med. Weekly, May, I88z.

7. Feeding against the appctite. Med. Register, Phila., April 2 and 9, 1887.

8. Food versus bacilli. Va. Med. Monthly, Richmond, December, I 888.

9. Vinegar and vinegar yeast. Times and Register, Philadelphia, July, I889.

Io. Reprint 1897 , Food and Tubercle. Transactions Tenth International Medical Congress, Berlin, I8go, Band iii., Abtheilung v., p. 30. The present excerpt being an addendum to the original 1890 article.

II. Feeding in the wasting diseases. Joint Report to Committee of Dietetics of Am. Med. Association, I89o, with Dr. John A. Cutter. Journal of Amer. Med. Association, July 26, I8go; Med. Bulletin, June, July, and August, I8go; N. E. Med. Monthly, August, I8go; Pac. Med. Jour., August. I8gu; Southern Practitioner, July and August, I890; Virginia Med. Monthly, June and July, 189o. On (I) Consumption, one hundred cases; (II) Bright's disease, fibroid tumor, and cancer; (III) Male neurasthenia.

12. Amcboid movements of the white blood corpuscle. Boston Journal of Chemistry, June, I876.

13. Hog cholera: its cause known. Western Rural, March 22, 1879.

14. Morphology of diseased blood. Southern Clinic, March, I879. 
15. Tolles'one-seventy-fifth inch objective: its history, uses, and construction. Am. Journal of Arts and Sciences, New Haven, August, 1879: Scienti fic Am. Supplement ; Journal de Micrographie, Paris, 1879.

16. Some details as to Tolles' 1-75 objective. The Amer. Monthly Microscopic Journal, August, r 895 .

17. Primer of the clinical microscope. Va. Med. Monthly, Aug. and Sept., 1879.

18. A new physical sign of the pre-tubercular state. Ready since 1877. Illustrated.

19. Pre-tuberculosis. American Monthly Microscopic Journal, May, I895.

20. Leavens and Man. Written by invitation of, and for, the Philosophical Society of Great Britain, 1884 . Many original illustrations.

2r. Morphology of syphilitic blood. Am. Jour. of Dental Science, Oct., I879.

22. Food as an rsthetic, chemic, physiologic, pathologic, and therapeutic. Am. Journal of Dental Science, January and February, 1880.

23. Abnormal entozoa in man. Virginia Med. Monthly, February, I881.

24. Use of the microscope in consumption. Journal of Microscopy, Phin's, September, 1881. 25. Second paper, ditto, 1882.

26. Tubercle parasite. Editorial. Scientific American, June 2, I882.

27. Preventive medicine and tuberculosis. Journal of the American Medical Association, 1897.

28. Partial syllabic lists of the clinical morphologies of blood, sputum, fæces, urine, foods, clothing, soils, etc. Book. Published by author, 1888 .

29. Use of the microscope. Book, not published, 1874 .

30. The esoteric bcauty and utility of the microscope. Jour. Amer. Med. Assoc., May 7. 1892. The Microscope, Jan., Feb., and March, I892.

31. Note on consumption. Philadelphia Med. and Surg. Reporter, May, I881. 32. Uterine disease sometimes called consumption. Transactions Medical Association of Georgia, 1883 .

33. The therapeutic drinking of hot water: its origin and use. Am. Med. Weekly, January 8, I883; Druggists' Circular, August, I883; London Lancet, September I5, I883; Journal d'Hygiène, October 25, 1883; Therapeutic Gazette; Scientific American; Constitutionnelle, and the medical and secular press of Paris.

34. Colloid disease. Alabama Med. and Surg. Age, March 2, I889.

35. Under what circumstances do the usual signs furnished by auscultation and percussion prove fallacious? Boylston gold medal prize essay, 1857 .

36. The American blood test for cattle tuberculosis. The New England Medical Monthly for July, I8g6; Americall Monthly Microscopic Journal, i 896.

37. Medical food ethics, now and to come. Secretary's address bcfore Section on Physiology and Dietetics, Amer. Medical Association, 1892 The Journal of the Association, 1893. 


\section{BOOKS AND PAMPHLETS.}

I._“ FAT TY ILLS AND THEIR MASQUERAUES. By EPHRAIM CUTTER, LL D., M.D, and Johs Ashburton CutTer, B.SC.. M.D. 'Being a contribution to clinical medicine for practitioners and students, to emphasize the inestimable value of the microscope in detecting the pre-stages of amaurosis, angina pectoris, apoplexy, Bright's disease, cataract, dementia, fatty heart, gall-stones, glaucoma, hemophilia. locomotor ataxia, etc., and the like value of American means of treatment in these pre.stages, and those advanced stages usually considered incurable.'

"That fat is the natural enemy of mankind every athlete knows, and if Dr. Cutter's book will better aid in getting rid of this persistent enemy it will not have been written in vain. A number of cases are given in the peculiarly intere,ting style of the author, and they serve conclusively to illustrate the points the author makes. The book is entertaining, and even if one does not agree with the author's conclusions, be will at least be interested in the manner of stating his case. As an addition to American medical literature it is unique and should find place in the advanced medical library." - The fournal American Mledical Associalion.

"Dr. Ephraim Cutter a man of indefatigable industry and an original thinker, has for many years been a close student of the influence of food in health and disease. He has paid great attention also to microscopy of the tissues and fluids of the body. The presentation, in this volume, of his views relative to the fatty degeneration of tissues and organs, lays great stress upon the effect of diet in both producing and curing this condition. The writers trace the ranifications of the fatty metamorphosis as they are exhibited in diverse disease-processes. The diversity depends upon the organs which may be attacked, but the writers teach that the pathological change is essentially the same in all structures. In treating these disorders the writers dwell much upon the use of hygienic and physiolngical agencies in addition to diet they point out the benefits of electricity, massage, cheerfulness, music, etc. "These are very important topics and have been assiduonsly studied by the authors." -The Medical Bulletin.

PAGES 106, CLOTH, \$1.

Il.-CUTTERS' MEDICAL MEMOIRS: To ConTAIN-I. THE TrCHNIQUe OF THE MICROSCOPE. II. THE GerM DISEASES III THE FA TTY Ills. IV. The Fibaoid Ills. V. The Gravel Ills. Vi. Ti1e Ills Due to Fibremia and allikd Conditions. Vil. The Cancerous or MLalignant Ills, VIII. Food in Motherhood. IX. Diseases of WoMEN, SPECIALly in tHE LiNe of WORK Established by THE SENior WRITER IN I868. X FEEDING IN ACUTE DISEASES. XI. Diseases OF the l'hroat. Xit. Ethics and Polemics of Medical Practice, Specially as to the Management of Chronic Disease. XiII. Music. Galvanisin, etc. SUBSCRIPTION PIICE. 5 .

It is hoped to issue the above during 1898 . The writing will be on the line of practical work in medicine as to diagnosis and management of disease.

III.-FOR OTHER PUBLICATIONS NOW IN PRINT, and for information regarding CUITERS' SCHOOL of MIICROLOGY for instruction of physicians in the use of the microscope, specially in the management of chronic disease, address

EPHRAIII CUTTER, M.D., JOHN ASHBURTON CUTTER, A.D., EQUITABLE BUILDING, IIO BROADWAY, NEW YoRk. 